\title{
BETWEEN ECONOMIC AND LEGAL ANALYSIS OF INCORPOREAL THINGS: A CRITICAL "NO" TO AEDILITIAN REMEDIES
}

CG Kilian *

\section{$1 \quad$ Introduction}

Holmes JA stated in Phame $v$ Paizes 19733397 (A) 420 ${ }^{1}$ the following, perhaps obiter, regarding the quality of incorporeal things:

The next question is whether the representation as pleaded is incapable of being read as bearing upon the quality of the shares. Now quality is a word with a fairly wide connotation. To preserve the mercantile usefulness of the Aedilitian remedies, I do not consider that the word should be given a restricted meaning. When one speaks of company shares of good quality, ${ }^{2}$ a relevant consideration is the percentage return after deducting expenses from income. If one speaks of buying "9 per cent shares", I consider that that can be said to relate to their quality.

This dictum indicates very interestingly the flexibility of the common law in aiming to ensure justice, equity, reasonableness and good faith. These four qualities ultimately arouse academic interest, particularly when Aedilitian remedies are involved - such remedies in the law are limited in number, ${ }^{3}$ which may necessitate reasonable extension of a remedy so as to resolve the factual circumstances under scrutiny in order to achieve justice in the commercial world. A fine example under the common law is to be found in the Justinian period where the jurists experienced no difficulty in developing the Aedilitian

* $\quad$ LLM (South African University System), Joint European Interdisciplinary Master - Master di Secondo Levello (Italian University System), Mastergrad (German University System) Magistrski Študij (Slovenian University System), Kiegészítõ Alapképzés (M.A.) (Hungarian University System).

$1 \quad$ Phame v Paizes 19733397 (A) 420 F-G. Hereinafter Phame v Paizes.

2 My emphasis.

3 Actio quanti minoris, actio redhibitoria; and in addition to the Aedilitian remedies the aggrieved person may make use of the actio empti to claim consequential damages. 
remedies to other things which were originally reserved for animals and slaves. ${ }^{4}$

In this paper the primary interest is in the quality of incorporeal things (that is, going concerns) and, therefore, a number of problems will be introduced to afford a correct starting point. The first problem identifies the unique similarities between Roman law principles, inter alia, latent defects in corporeal things and a dictum et promissum. The seller has a common law duty to deliver the merx free from any defects that render the merx unfit or impair the usefulness of the merx for the purpose for which it was sold. Mostert stated:

'n Verborge gebrek is 'n gebrek in die koopsaak van 'n nieonbenullige aard wat die gebruiksnut van die saak affekteer en wat nie aan die koper bekend was tydens die kontraksluiting, en ook nie deur hom met redelike sorgbesteding opgemerk sou word nie. ${ }^{5}$

At present, it is hardly possible to imagine how the buyer can reasonably conduct an appropriate inspection when incorporeal things are acquired, for example, a listed share that mainly exists in electronic format. One might immediately draw the conclusion that an aggrieved buyer has no remedy because of the impossibility of identifying a defect. However, both corporeal and incorporeal things share a common foundation and that is verbal or oral communication prior to the contract. Before the contract is entered into, the seller could verbally communicate the qualities of the thing to the buyer. $A$ verbal statement bearing on the qualities of the merx allows for the dictum et promissum to exist when the statement goes beyond mere praise and recommendation of the merx - a false statement. Irrespective of whether the

$4 \quad$ See in general Digesta 21138 10; Digesta 21138 4; Digesta 21 11; Daube (ed) Studies in the Roman Law.

5 See Mostert, Joubert and Viljoen Die Koopkontrak 185; Wessels 1920 SALJ 265; Knight V Trollip 19483 SA 1009 (D) 1013; Dibley v Furter 19514 SA 76 (K) 81 observes: "...the test whether the usefulness of a res has been impaired is objective in the sense that it must attach to the res and must not be dependent upon the whim of the purchaser."; Holmdene Brickworks v Roberts Construction 19773 SA 670 (A); Truman v Leonard 1994 4 SA 371 (SOK); Van der Merwe v Meades 19912 SA 1 (A); De Vries v Wholesale Cars 19862 SA $22(\mathrm{O})$. 
seller communicated the statement deliberately or innocently, he/she is nevertheless liable to make good of what he/she has negotiated with the buyer. The dictum et promissum is, therefore, the same as with the remedies available for latent defects - the merx acquired must be fit for its purpose. According to Rogerson: 6

First, any express promise as to quality will be enforced, whether given formally by stipulatio or informally as part of the terms of the contract of emptio venditio itself. Questions of construction may arise: if they do, promises are construed reasonably, rather than in favour of the seller. Thus, if a seller states that a slave is steady and hardworking, the buyer cannot complain if he finds him with less than a philosopher's gravity or unwilling to work night and day. However, if the seller promises an excellent cook, he is liable if he supplies one of only moderate ability.

When hardworking in the above example is a written contractual term, an aggrieved contractual party will not use the dictum et promissum to achieve justice in the commercial world. Instead, the aggrieved party will make use of the general principles of the breach of contract. It is fair to conclude that the Aedilitian remedies are the same as the general principles applicable to breach of contract - the buyer of a slave who is less than a philosopher or who is unwilling to work day and night may accept or reject the slave. Obviously, a high price paid, per se, does not constitute breach of contract or a dictum et promissum, but the buyer in ancient times could reject the contract by making use of the common law principle laesio enormis. ${ }^{7}$ Needless to say, laesio enormis is only relevant to value or price should it be established, after the contract has been entered into, that the price paid is very high in relation to the true value of the merx. Although laesio enormis was abolished nearly 60 years ago in South Africa, it remains a very important pillar in the present article owing to the additional protection which it offers a contractual party under certain circumstances, which is the same as the actio redhibitoria, that is, to return the parties to their respective positions prior to the contract. It is,

6 See Daube (ed) Studies in the Roman Law 112.

7 See Jamneck 1997 JSAL 637. 
therefore, appropriate to conclude that the common law remedies, dictum et promissum and laesio enormis, share a common characteristic and that is that the true value of the merx differs prior to the contract. To consider the term 'value' within an economic context, different economic formulas or ratios are used to indicate whether incorporeal things could possess 'good' or 'bad' qualities, perhaps, to eschew Justice Holmes' dictum.

\section{Shares}

\subsection{Overview}

To determine the characteristics of shares it is important to employ reliable methods to calculate company productiveness, which enable the latter to be compared with any other company's productiveness in the same economic sphere. $^{8}$ These methods must be universally recognised otherwise the objective determination of what amounts to 'good' quality shares would be too vague for any interested buyer. Mostly, these methods use net profit as an element to calculate the attractiveness of an investment. A clear example is that of share ratios or share statistics. The downside of net profit is that it only indicates past company successes and is not an element that guarantees future productivity. However, the importance of net profit in relation to past productivity might be illustrated by the ratio below. ${ }^{9}$

\subsection{Book value (net asset value)}

The calculation of the book value of shares depends on financial information provided by a balance sheet as well as by a disclosure of the total number of issued shares. ${ }^{10}$ The main purpose of a balance sheet is to disclose past

$8 \quad$ S v Isaacs 19682 SA 187 (D) 196.

9 Bloomfield Company Accounts 118.

10 Donaldson Investments v Anglo-Transvaal Collieries 19793 SA 731 H - 732 B. Net asset value or book value of shares is calculated as market cap. This is incorrect. 
liabilities, assets and equity. ${ }^{11}$ Equity is calculated by deducting liabilities from assets and then on dividing equity by the number of issued shares, one arrives at the book value per share. If the book value of a share in comparison with other companies in the same industry is higher, this figure could indicate that the company is saddled with fewer liabilities or that the company is creating net profit more effectively - net profit increases equity in the balance sheet. The difference by which equity exceeds liabilities is known as the target debt to equity ratio.

\subsection{Target debt to equity ratio}

The capital structure of any company will consist of equity, assets and liabilities. The proportion of equity to assets or proportion of equity to liabilities is not uniform for all types of companies, for example, retail, manufacturing and industrial companies. However, all these companies in the different economic spheres must display a sufficient target debt to equity ratio. The greater the proportionality of equity to liabilities, the greater the book value per share. ${ }^{12}$

\section{$2.4 \quad$ Listed share price}

Market forces (or market sentiment) mainly influence the price movement of a listed share. For example, the market sentiment could anticipate an increase or decrease in the future company profitability of a company, which could increase or decrease the listed share price. To avoid sell-offs when the listed price per share decreases, a company which is experiencing profitability difficulties will issue a "profit warning". ${ }^{13}$ The latter is simply a statement made by the board of

11 See Cilliers et al. Corporate Law 362 and 407; Berelowitz 1979 De Rebus 199 for a discussion of the differences between "market value" and "market price".

12 Dempsey and Pieters Finansiële Rekeningkunde 69; Correia et al. Financial Management 512.

13 Public commentary Sake Rapport 3. The present writer interviewed PSG Securities Pty (Ltd), Parktown, as a result of the content of this article and is grateful for their explanation of the incorporeal business environment. 
directors explaining the reasons why the company is experiencing such difficulties. It is, therefore, reasonable to conclude that the value of a listed share depends greatly on book value and/or the target debt to equity ratio. This comparison is important for one to be able to understand or to calculate the value of control over a company when a buyer decides to make an offer to purchase.

\section{The value of control}

\subsection{Overview}

Generally, the terms 'value of a company' and 'value of control' are used as synonyms. ${ }^{14}$ In this regard, Beuthin and Luiz rightly contrast this terminology although it should be noted that his example is not conclusive:

There are many reasons why a company might wish to acquire an indirect control over the assets of another company, the target company, by acquiring its shares. For example, if because the management of the target company has not appreciated the true value of its assets, or through lack of skill and poor management has failed to use those assets to optimum advantage, a situation might be reached where the net asset value per share of a company was, say, R2, while the market price of its shares was only $R 1,25$. Should the acquiring company be able to acquire the shares at $R 1,60$, it would gain control over the assets worth 40c per share more. These assets could subsequently be turned to better account or be bonded to raise money for further ventures. ${ }^{15}$

Compare the above to the following circumstance. ${ }^{16}$ In company $A B C$ the majority shares were sold for 407 cents per share when the same share was traded on the securities exchange for 125 cents. One's immediate reaction would be to respond that the 407 cents per share is overvalued or very

14 Anthony Rethinking the Rules 51.

15 Beuthin and Luiz Company Law 253.

16 Berelowitz 1979 De Rebus 199. 
expensive in comparison to the listed share price or book value per share. To decide whether a price of 407 cents is actually overvalued, however, we should consider the economic formula that is frequently used by businessmen, accountants or similar professionals to calculate the future value of a share.

\subsection{Basic or simple economic formula}

In Steyn v Davies 1927 TPD 651 the parties used a simple method to calculate the future value of the following business. ${ }^{17}$

\begin{tabular}{|l|r|}
\hline 24 cows and a bull & $£ 850$ \\
\hline 6 calves & $£ 30$ \\
\hline Utensils etc & $£ 60$ \\
\hline Goodwill & $£ 160$ \\
\hline Total (current price) & $£ 1100$ \\
\hline
\end{tabular}

In Steyn $v$ Davies the parties negotiated on the purchase price largely in exchange for 24 cows and a bull. ${ }^{18}$ In the above example we observe that the business was sold for more than the net asset value owing goodwill. The court, with respect, did not take into account the business principle concerning goodwill and as a result two economic principles were disregarded. Firstly, the court ignored future value and secondly, the uncertainty of the business environment in which a company operates. ${ }^{19}$ The next paragraph attempts to explain the commercial principle concerning goodwill and how to calculate future equity/value by making use of the complex economic formula used at present.

17 Steyn v Davies 1927 TPD 651, hereinafter Steyn v Davies.

18 Steiner Financial Calculations 52 for insightful definitions and calculations of future value.

19 See par 7.1.2.3 of this article. See Cilliers et al. Corporate law 200. The authors explain the double-entry principle when dealing with goodwill. 


\subsection{Complex Economic Formula}

\subsubsection{Overview}

Capital constitutes the cornerstone of the complex economic formula. The writer is aware that old authorities or case law are sometimes replaced by newer and more sophisticated interpretations of factual circumstances, but to appreciate the philosophy behind capital it is important to focus on the explanation contained in the case of Ammonia Soda $v$ Chamberlain (1918) 1 Ch 266 CA. $^{20}$ In the Ammonia Soda case, the court decided, clearly and precisely, the importance of capital in relation to perpetual succession. Fixed capital compromises capital invested in fixed assets, while circulating capital represents that portion of the internal or external capital used by the company to conduct its business. Using modern day terminology, capital originates either as internal or external capital (weighted average cost of capital), depending on the circumstances of finance. Since a company's focus falls on circulating capital, the intention is that the internal rate of return must be greater than the weighted average cost of capital, which indicates that the company is creating circulating capital. This terminology suggests a focus area for accountants or similar professionals who whish to measure future value or positive goodwill. ${ }^{21}$

\subsubsection{The formula}

The following explanation clarifies the manner in which economists or accountants attempt to accord incorporeal things value or qualities. The complex economic formula is referred to as 'shareholder value added'. ${ }^{22}$ It

20 Pretorius et al. Company Law 586.

21 Black et al. Shareholder Value 23 indicates: "We raise capital...sell it at an operating profit. Then we pay the cost of the capital. Shareholders pocket the difference."

22 Walsh Ratios 260-275. The author explains "shareholder value added" in great detail; Vigario Accounting 285; Katzoff $v$ Glaser 19484 SA 630 (T) 636 where the court indicates: "...the value of anything is what it is worth at the time..."; Dean v Prince [1954] Ch 409 and [1954] 1 ALL ER 749 (CA) where this court argued that there is no accountancy principle which fixes or limits value calculation of shares; Donaldson Investments v Anglo-Transvaal Collieries 19793 SA $731 \mathrm{H}-732 \mathrm{~B}$ where it is argued that 
takes the following elements into consideration but is not limited thereto owning to accountants or similar professionals discretion: the future economic life of the business, future turnover, future tax, future fixed asset value and future net working capital. ${ }^{23}$ The fixed asset forecast as well as the net working capital forecast must be set off against the net operating profit after tax, in order to determine the net cash flow for each year within the economic life expectancy of the business. If the parties agree that the economic life expectancy of the business is four years, then the turnover should be forecast for the following four years. What makes forecasting complicated is the fact that working capital must be linear to turnover, that is, forecast increases in turnover require additional internal or external capital to support continuation. ${ }^{24}$

The most complicated factor entails the next step: to use the weighted average cost of capital (WACC) and terminal value (TV) correctly. The purpose of WACC is to discount the net cash flow for each future year (four years) to present value. ${ }^{25}$ The terminal value is calculated by dividing the future net cash flow (over four years) by the weighted average cost of capital. Then the present value of the business and the terminal value are simply added together - 'total present value'. The fixed and current liabilities as disclosed in the very last audited balance sheet must be deducted from the forecast regarding 'total present value'. If the difference is positive, it indicates added future equity hence the term 'shareholder value added'. This added equity indicates an increase in future book value per share.

to calculate shareholder value is to multiply earnings per share by the number of issued shares.

23 Katzoff $v$ Glaser 19484 SA 630 (T) 636. Should future depreciation of fixed assets be included in this formula? The parties must reach consensus as to what should be taken into consideration.

24 Walsh Ratios 260-275; See Berelowitz 1979 De Rebus 201. Berelowitz referred to the Winter case where there was depreciation of assets for tax purposes. Should deferred tax be taken into consideration? See $\mathrm{n} 25$.

25 Novick $v$ Comair Holdings 19792 SA 116 (W) 146 F-G with emphasis on G, Colman j states: "Then, when a view has been formed about probable future profitability, a factor has to be applied to that in order to arrive at a value of the company." The factor is most likely the "terminal value". 


\subsubsection{Purpose of the complex economic formula}

Generally the economic formula explains the financial scenario that, if a company increases its turnover while future liabilities remain at least constant, the company will most likely increase in future value owing to added equity. ${ }^{26}$ It is accordingly put forward that 407 cents per share could be compared with the forecast book value of shares - gain control over the assets worth $13 \mathrm{c}$ per share more.

\begin{tabular}{|l|l|}
\hline Sold & 407 cents per share \\
\hline "Shareholder value added" over 4 years & 420 cents per share \\
\hline
\end{tabular}

To calculate whether liabilities (WACC) will be increased in the future depends largely on the capital structure employed in the company at present, as stated by Vigario:

In practice, it is difficult for a company to determine the target debt to equity ratio, but it will be guided by the capital structure of similar quoted companies. ${ }^{27}$

But this complex economic formula immediately provokes another question: how accurate is it? As indicated above, added equity depends largely on future forecasts and it is commonsense that the future is not certain but uncertain. This question leads us to the next element as identified by Beuthin and Luiz.

26 See Dean v Prince [1954] Ch 426 examines the following: "If a business is making a loss, that shows that its assets, regarded as an entity, are not a good investment. A purchaser will decline, therefore, to buy on that basis."

27 Vigario Accounting 285. 


\section{$4 \quad$ The True Value of a Company}

\subsection{The most important factors}

Beuthin and Luiz identified elements which exhibit non-monetary value and they are, inter alia, customer appreciation, history, clever management (business acumen), ambition, human value, fear, hope, guess work, et cetera. Non-monetary elements cannot be calculated. To illustrate the latter point more clearly in terms of a financial perspective, we will make use of the following example of a company $(A B C)$ listed on the Johannesburg Securities Exchange since $1965:^{28}$

\section{Extract from income statement}

\begin{tabular}{|l|c|c|c|c|}
\hline Year & 2001 & 2000 & 1999 & 1998 \\
\hline Top Line & 2193 & 2319 & 2292 & 1016 \\
\hline Operating profit & 250 & 195 & 296 & -56 \\
\hline
\end{tabular}

\section{Extract from cash flow statement}

\begin{tabular}{|l|c|c|}
\hline End & 2001 & 574 \\
\hline End & 2000 & 447 \\
\hline End & 1999 & 287 \\
\hline End & 1998 & 48 \\
\hline
\end{tabular}

\section{Extract from balance sheet}

\begin{tabular}{|l|c|c|c|c|}
\hline Year & 2001 & 2000 & 1999 & 1998 \\
\hline Total assets & 710 & 679 & 552 & 187 \\
\hline Debt to equity & .25 & .29 & .54 & .51 \\
\hline
\end{tabular}

28 McGregor's Security Exchange Digest 2002 May to Aug 79. See Gradwell v Rostra Printers 19594 SA 419 (A) 423. The Appellate Division held that if liabilities exceed assets, the shares will be worthless. With respect, this is not correct; Ex parte Natal Coal Exploration 19854 SA 279 (W) 282 states: "The prospect of a future stream of dividends may serve to enhance the capital value of his shares"; and "A shareholder is a participant in a risk venture embarked on with a view to making profits. He has the prospect that if profits are made a dividend may be paid." 


\section{Notes}

- Although the weighted average cost of capital is not disclosed in the financial statements, we may assume that the internal rate of return (IRR) is greater than the weighted average cost of capital (WACC) owing to the increase in cash in 2001.

- Listed share price in 1999 is R18,00 and R4,80 in 2001.

In the above example it may be observed that in 1999 the listed share price is nearly four times higher than the price per share in 2001. Is $A B C$ less in value in 2001 than in 1999 due to the decrease in share price ${ }^{29}$ By making use of the complex economic formula, it is fair to assume that the formula would forecast no 'added equity' in 2001 when observing the capital structure in 1998. ${ }^{30}$ This example indicates clearly that $A B C$ has value, but value is nonmonetary owing to intelligent business decisions to alter a 'bad' capital structure into a 'good' capital structure, evident in 2001. If the buyer of a business possesses very little business acumen may he/she sue to return the parties to their respective positions prior to the contract owing the share price in 1999 ? This answer seems to be in the affirmative. Holmes JA stated (as quoted earlier):

...to preserve the mercantile usefulness of the Aedilitian remedies, I do not consider that the word [value] should be given a restricted meaning.

This statement directs us to the following paragraphs regarding the consequences of judicial discretion in the commercial world.

29 See Nortjé Dividende preface par 1.2 where Nortjé states: "Die inligting vervat in huidige didvidendaankondigings kan nie deur beleggers gebruik word om die volgende JAar se verdienste per aandeel van ' $n$ maatskappy te voorspel nie. Beleggers sou dus nie die inligting vervat in didvidendaankondigings kan gebruik om bogemiddelde opbrengskoerse te genereer nie. Inligtingswaarde van dividende is dus onwaarskynlik as verklaring van ' $n$ maatskappy se dividendbeleid op die waarde van sy gewone aandele."

30 The best way to forecast the future is to create it. 


\section{$5 \quad$ The difficulties of discretion}

\section{1 "I do not consider" and economic consequences in general}

Discretion is an instrument to achieve 'fair play'. ${ }^{31}$ Grossfeld very interestingly observes the following:

That is why, when talking about 'fair play' we may have different games in our mind's eye. This might trigger different associations and might influence our views as to what we regard as being fair, correct, and within the 'rules of the game'. ${ }^{32}$

The French constitutional lawyer de Condorcet interpreted discretion as freedom. Certainly, to a large extent, the South African courts have the freedom to ignore a particular action and to replace the plaintiff's action with another as stated by Wessels j:

....if ordinary goods or chattels are sold as may be bought anywhere, the court will not order specific performance. ${ }^{33}$

In the Benson v SA Mutual Life Assurance Society 19861 SA 776 (A) the Appellate Division departed from Wessels $\mathrm{J}$ in so far as it held that a plaintiff has a right to choose his remedies and this right is not subject to judiciary freedom when a particular action is to be substituted with another. This departure may seem strange, but in order to appreciate this judgment the present writer will briefly refer to the factual circumstances of this case. The plaintiff purchased 171500 shares, received 107900 and consequently claimed the difference (63 600). The court granted 63600 shares to the plaintiff although other similar shares were easily available on the open market. Coincidentally, by means of this technical departure from the Wessels j dictum

31 When are justice, fairness and reasonableness achieved? Otto $v$ Heymans 19714 SA 148 (T) and Zuurbekom $v$ Union Corporation 19471 SA 514 (A) 546 indicate the difficulties.

32 Grossfeld 1997 JSAL 648 and 669; De Villiers 1997 JSAL 615.

33 Wessels Law of Contract 3137; De Condorcet 1793-1794 http://socserv2.socsci.mcmaster.ca/ 14 Feb. 
the Benson v SA Mutual Life Assurance Society effected 'fair play' as it did not allow for an increase in book value per share or earnings per share.

\begin{tabular}{|l|c|c|}
\hline & $\begin{array}{c}\text { Share structure, } \\
\text { Benson case }\end{array}$ & $\begin{array}{c}\text { Share structure, } \\
\text { Wessels' dictum }\end{array}$ \\
\hline Total shares & 200000 & 200000 \\
\hline Issued & 171500 & 107900 \\
\hline Unissued & 28500 & 92100 \\
\hline Net profit & 500000 & 500000 \\
\hline Elper share & 2.9 & 4.63 \\
\hline Price per share & $\mathrm{R} 6$ & $\mathrm{R} 6$ \\
\hline Pricelearnings & 2.06 & 1.29 \\
\hline
\end{tabular}

The consequences of unfounded judicial discretion in the commercial world could be far reaching. The ratio between earnings per share and price per share is important in calculating investment attractiveness (price/earnings ratio). According to a financial analyst it will take 2.06 years to equal the price of the share instead of 1.29 years -1.29 years is more attractive to an investor. ${ }^{34}$ It is, therefore, very important that courts in South Africa should recognise the 'rules of the commercial world' when they are ignoring or applying remedies so as to prevent the creation of artificial share value or investment attractiveness.

\section{$6 \quad$ Aedilitian remedies}

\subsection{Case law, legal certainty and business acumen}

The facts of Janse van Rensburg v Grieve Trust CC [1999] 3 All SA 597 (C) are simple. ${ }^{35}$ The appellant and respondent concluded an agreement to acquire a

34 Bloomfield Company Accounts 118. See Kerr Law of Contract 599 who observes the following: "Adv Rob van Deventer is critical of the proposition that in all contracts the aggrieved party has a right to specific performance."

35 Hurter 1988 MBL 134-142. 
vehicle, whereby payment was to be effected partially by a used vehicle. Pending conclusion of the contract the appellant believed innocently that the used vehicle was a 1993 model. After conclusion of the contract the vehicle was found to be a 1989 model and consequently to be less in value. The court a quo followed the decision in Wastie v Security Motors 19722 SA $129(\mathrm{C})^{36}$ where this court extended the Aedilitian remedies to defects under trade-in agreements. The respondent successfully claimed $\mathrm{R} 9800$, being the difference in value between the 1989 and the 1993 year model. On appeal against the judgment of the Magistrate's court the appellant argued that the court a quo had wrongly decided for the reason that the factual circumstances in Wastie $v$ Security Motors were distinguishable. The court held that Wastie v Security Motors had been correctly decided owing to the fact that the Aedilitian remedies are available even where innocent misrepresentation exists - justice, equity and reasonableness demand that a contractual party be protected from a dictum et promissum irrespective of the legal nature of the contract. This decision was significantly influenced by Phame $v$ Paizes decided nearly 30 years earlier.

In Phame $v$ Paizes the buyer concluded a contract of sale to acquire a business. After the contract of sale was entered into the buyer realised that the agent had misrepresented the municipal rates as R4 646 instead of R14 736 per annum. Of course, the seller did not interfere to correct the mistaken belief of the buyer. The Appellate Division concluded that although the misrepresentation was innocently made, nevertheless it fell within the ambit of a dictum et promissum. ${ }^{37}$

What is the key difference between Wastie $v$ Security Motors and Phame $v$ Paizes? Why is it important to distinguish between these two cases? Business acumen may be the key difference. Business acumen and disclosure of business acumen through financial reporting remain problematic in South Africa. A fine example of disclosure of business acumen is to be found in asset

36 Wastie $v$ Security Motors 19722 SA 129 (C). Hereinafter Wastie v Security Motors.

$37417 \mathrm{H}$ and $418 \mathrm{~A}-\mathrm{C}$. 
swap. Business enterprise A is the owner of a fixed asset valued at R200 000. This asset is located in a high crime area which negatively affects the turnover of the company. Business enterprise $B$ owns a fixed asset in a low crime area, valued at R450 000. Enterprise A swaps its fixed asset with that of B's fixed asset perhaps because company $B$ prefers to conduct business in a high crime area. ${ }^{38}$ On the balance sheet of $A$ the fixed asset will be indicated as R200 000 accordingly to the general accounting principles. If the seller of $A$ did not disclose the asset swap prior to the contract, could this be interpreted as a false statement since turnover decreased to R50 000?

Extract from income statement before acquiring the incorporeal thing

Asset swap

\begin{tabular}{|l|r|}
\hline Turnover & R 100000 \\
\hline Net profit & R 20000 \\
\hline Issued shares & 2000 \\
\hline Earnings per share & R 10 \\
\hline
\end{tabular}

Extract from balance statement before acquiring the incorporeal thing

\begin{tabular}{|l|r|}
\hline Asset & R 200000 \\
\hline ROTA & $50 \%$ \\
\hline
\end{tabular}

\section{Extract from income statement after acquiring the incorporeal thing}

No Asset swap

\begin{tabular}{|l|r|}
\hline Turnover & R 50000 \\
\hline Net profit & R 10000 \\
\hline Issued shares & 2000 \\
\hline Earnings per share & R 5 \\
\hline
\end{tabular}

Extract from balance statement after acquiring the incorporeal thing

\begin{tabular}{|l|r|}
\hline Asset & R 200000 \\
\hline ROTA & $25 \%$ \\
\hline
\end{tabular}

38 See Ex parte Satbel: In re Meyer v Satbel 19844 SA 347 (W) 359. Levin v Feld and Tweeds 19512 SA 410 (A) 414 observes: "It is no part of the business of a court of justice to determine the wisdom of a course adopted by a company in the management of its own affairs." 
If $A$ is sold due to its impressive ROTA ratio, the new owner or purchaser may find himself in a painful situation. Whether a statement made by the seller concerning the quality of his or her business during the negotiation process entails praises depends on various circumstances. In Bradford-on-Avon Assessment Committee $v$ White 1898 (2) QB 630 the court held that the seller's personal (subjective) considerations of value or quality must be excluded during the negotiation process, unless it is special qualities. A special quality could, for example, be asset swap (evidently an impressive ROTA ratio), but there is no modern South African case law to support this asset swap as a special quality.

Although the calculation of ROTA depends on financial statements, financial statements have a downside to their effectiveness owing to their generic terminology, for example, fixed asset. To disclose specific financial terminology in isolation to a prospective purchaser, the law requires that a legal duty must exist between the seller and the purchaser. Under South African law, unexplained generic terminology in detail or terminology presented vaguely may possibly be interpreted as innocent misrepresentation for which the law requires no fault for liability. The shortcoming to innocent misrepresentation is that the aggrieved party is not entitled to claim damages unless it could be interpreted as praises. By making use of the above information we can analyse A's performance in a meaningful way: A cannot achieve the same net profit prior the contract, unless the purchaser employs the same degree of future business acumen. ${ }^{39}$ Irrespective of whether the decrease in turnover constitutes a dictum et promissum, the next paragraph identifies the unique qualities of incorporeal things as a ground to avoid Aedilitian relief. 


\section{$7 \quad$ The acquisition of incorporeal things}

\subsection{Overview}

During the Glossator period, the Glossators extended the application of the Justinian Aedilitian remedies even further by providing additional protection for an aggrieved person, the rule of laesio enormis. In terms of this rule an aggrieved person could rescind the contract entered into when the price paid for a thing was very high in comparison to the thing's true value. It is clear from this rule that value depends inherently on quality, but there appears to have been controversy before 1952 regarding what quality amounts to. Dias explains the inability of the judiciary to apply this rule properly:

The precise scope of the extension remained in some doubt. Some of the old authorities applied the rule only to valuable movables, while others suggested no such limitation. Until 1949 the South African case law showed no hesitation in applying it to movables, but there were dicta importing the restriction to valuables. Indeed, in one case it was applied to the sale of goodwill, ${ }^{40}$ an incorporeal. The question of what constituted a 'valuable movable' remained unanswered. Was there a specified value, or was it relative to the means of the party? Voet, though he mentioned the limitation did not refine it, but in one passage he treated an article worth 10 aurei as being valuable. In the decision at first instance in Tjollo Ateljees Bpk. v. Small, the Court refused to commit itself to an answer, but held that goods worth $£ 10$ were valuable. In 1949 this case was unanimously reversed by the Appellate Division. Laesio enormis as a whole was condemned by all the judges, while the extension to movables, especially by Voet, was strongly criticised by Van den Heever, JA and Schreiner, JA, thought that the doctrine was confined to immovables. ${ }^{41}$

The above dictum reveals the difficulties to achieve equity in the commercial world to allow the buyer a reduction of the purchase price because of innocent misrepresentation that cannot be made good. Is it possible to make misrepresentations regarding the future? Roman jurists indicated that there are

40 My emphasis.

41 Daube (ed) Studies in the Roman Law 46, 49. Legislation adopted in 1952 by the Union of South Africa abolished this rule. For comparative legal analysis into a remedy for reduction of price see Bergsten and Miller 1979 AJCL http://www.cisg.law.pace.edu/ 25 Mar. 
certain things in the commercial world which do not possess true value or quality. Those things are excluded from the leasio enormis relief because the thing constantly fluctuates in value, for example, insurance, annuities, compromise and speculative sales. ${ }^{42}$ In such an event, innocent misrepresentation has no legal foundation that true value should prevail. For our purposes, only a compromise and speculative sales are important for discussion.

\subsection{Speculative sales}

\subsubsection{Overview}

The Roman law principle, which has been disregarded in recent years, is that of emptio spei (hope of a thing). Concerning the legal nature of emptio spei, Professor Kerr refers to Pomponius (English translation) as persuasive authority:

Sometimes, indeed, there is held to be a sale even without a thing, as it was, a chance. This is the case with the purchase of a catch of birds or fish or of largesse showered down. The contract is valid even if nothing results, because it is a purchase of a hope.

Professor Kerr explains the relevance of Pomponius' dictum in modern times furthermore as follows:

[G]enerations of students have learnt that one can buy a spes ... and have wondered about the relevance of their newly acquired knowledge because no-one nowadays hears of anyone throwing largesse or buying hope of a fisherman's or fowler's catch... 43

The words 'sale' or 'buy' are often thought to be synonymous as far as the essentialia of a contract of sale are concerned, which is a popular misconcept-

42 Huber 36 7; Voet 18 15 5; Digesta 1818 1; Digesta 191 12; Voet 18515 in Daube (ed) Studies in the Roman Law; Kingsley v African Land Corp 1914 TPD 666, 674; Cotas v Williams 19472 SA 1154 (T) 1161.

43 Digesta 18181 in Kerr Law of Contract 27; Schulze 2001 SA Merc LJ 616. 
ion expressed by those persons who have become interested in the financial or stock markets. Due to the fact that generations of students have wondered about the relevance of Digesta 18181 , it is fair to conclude that Roman law is at present regarded as being merely historic and rarely of any relevance in solving modern commercial law problems such as business acquisitions. In order to decide on the direction which this dictum should follow in respect of modern commercial problems, we must make reference to the following. To a financial analyst this dictum resembles the characteristics of a forward contract. ${ }^{44}$ Such a contract is a contract to pay a current price for a future asset where the future value of the asset may be higher or lower than the current price. The current price is based on a formula, which is agreed to in the present. For instance, two persons conclude a contract in 2001 whereby the one person will buy a box of red cherries for R100 in the year $2010 .{ }^{45}$ If the red cherries reach a market value of $\mathrm{R} 900$ in 2010 we conclude that the red cherries was sold for a bargain in 2001 , conversely, obviously a loss if there is no box of red cherries in 2010 - irrespective of the outcome the contract remains valid. ${ }^{46}$

The above explanation enables us to reconcile the published doctoral thesis of Naudé with the element of future uncertainty. ${ }^{47}$ Naudé explains that the Aedilitian remedies are not available in the event of individual sale of shares, but are more likely to be relevant if a person purchases all the shares in a company. This is due to a very ingenious German construction that implies that all the shares are, in fact, the corporeal assets of the business and are

44 A forward contract is the same as a future contract, the only difference being that a future contract is listed on the South African Futures Exchange (SAFEX); See Kilian 2005 Comp Lawyer 154. In this article the researcher discusses a forward, option and lease contract.

45 See Katzenellenbogen v Mullin 19774 SA 855 (AD) 878 H; Dean v Prince [1954] Ch 409 and [1954] 1 ALL ER 749 (CA); Salisbury Portland Cement Co Ltd v Edwards Timber \& Lime Industries (Private) Ltd 19622 SA 167 (SR); Katzoff $v$ Glaser 19484 SA 630 (T) "...the value of anything is what it is worth at the time". See Bergsten and Miller 1979 AJCL http://www.cisg.law.pace.edu/ 25 Mar with special reference to the 1964 Hague Conference.

46 Berelowitz 1979 De Rebus 199. The 'value test' assumes that the value of a commodity is the price paid for the commodity, if this complies with the three requirements for value as set out by Colman j in Novick v Comair Holdings 19784 SA 671 (W).

47 Naudé Maatskappy Direkteur 148-152; Delport Verkryging van Kapitaal 637. Delport states that a shareholder must have a remedy in the event of defects; De JAger $v$ Grunder 19641 SA 446 (A) 457; Botha v Van Niekerk 19833 SA 513 (W). 
technically the merx in the sale agreement. It is furthermore argued by Naudé that the German construction alters the legal nature of shares and should be viewed cautiously - incorporeal things being characterised as corporeal. ${ }^{48}$ His argument is ruthlessly criticised by fellow academics. ${ }^{49}$ The present writer concurs with Naudé, based on the idea that the substance matter of a forward contract is inherently different from a contract of sale. In a contract of sale the substance matter is red cherries (corporeal) but in a forward contract the substance matter is the future (incorporeal) value of red cherries - substitute red cherries with shares and the German construction immediately discloses its imperfection because the acquisition of incorporeal things is the acquisition of a hope. In Novick $v$ Comair the court paid attention to two expert opinions (those of the auditors Potter and Chapman) where they stated that the best method to value a business is the ability of the company to produce or to create future value ('added equity'). ${ }^{50}$

\subsubsection{Conclusion - acquisition of incorporeal things}

There are certain things in the commercial world which do not possess true value and they are the five exceptions discussed earlier - rule of leasio enormis. Why should the Aedilitian remedies be treated differently in this regard? It is, therefore, of interest to note that equity is preserved in the commercial world for not allowing a reduction of the purchase price of an incorporeal thing because of the impracticality to construct misrepresentation of an incorporeal thing since the acquisition is based on hope. ${ }^{51}$

In conclusion, brief mention is made of the following innovation and/or the creativity that the contractual parties could bring to bear. The parties could employ an expert or arbitrator (receptum arbitrii) to establish whether the

48 Vintcent Be Your Own Broker 220; Ex parte Natal Coal Exploration 19854 SA 279 (W) 282.

49 See Hurter 1988 MB 143 where Hurter critises as follows: "Dit is onduidelik waarom en die indruk word geskep dat hy ' $n$ prooi is van ' $n$ konsepsuele probleem ten aansien van onliggaamlike sake...".

50 Novick v Comair Holdings 19794 SA 116 (W) 146.

51 See Vintcent Be Your Own Broker 220. 
incorporeal thing has the ability to produce future value. ${ }^{52}$ The parties could agree on certain elements that are necessary for the calculation of future value to which an arbitrator must give diligent attention or else case law may limit the opinion of the arbitrator. In Salisbury Portland Cement $v$ Edwards Timber \& Lime Industries 19622 SA $167(\mathrm{SR})^{53}$ the court held that if an arbitrator sets a current price for a business it must be calculated on the principles of fairness and reasonableness. ${ }^{54}$ This decision, with respect, is very vague because economic formulas deal with future uncertainty. ${ }^{55}$ When an arbitrator fixes an unduly low or high price it indicates improper conduct instead. ${ }^{56}$ The court's duty, therefore, is to determine whether the arbitrator did act properly when valuing the business instead of analysing whether the calculation of future value is reasonable or fair. ${ }^{57}$ An excellent example is the difference between the economic life and the practical life of a thing. A computer has an economic life of 4 years but a practical life of 25 years - its future value relates only to its economic life. ${ }^{58}$

\subsubsection{Controversial case law}

Academics frequently exclude old case law because of their perceived impracticality in the modern organised society. The author shares the same opinion, but older case law illustrates the importance of not ignoring financial principles by applying the law unilaterally to a problem. In Steyn $v$ Davies (discussed earlier) the seller did not disclose four cows that were in the process of calving and that in the future the buyer would not be able to sell the same quantity of milk as negotiated. When the buyer appreciated these

52 Katzoff $v$ Glaser 19484 SA 630 (T) 636; Berelowitz 1979 De Rebus 199; Novick v Comair Holdings 1978 4SA 671 (W).

53 See $\mathrm{f} 45$.

54 Dean v Prince [1954] 1 ALL ER 749 (CA) 636.

55 Katzenellenbogen v Mullin 19774 SA 855 (AD) $878 \mathrm{H}$.

56 Daube (ed) Studies in the Roman Law 23 and 62.

57 Katzenellenbogen $v$ Mullin 19774 SA 855 (AD) $882 \mathrm{E}-\mathrm{F}$ states "... I would accept that the potential of a company's business activities inevitably affects the value of its shares ... person skilled in the valuation of shares ... would take other factors into account as at the relevant date, e.g., risks inherent in this kind of business." But the Pietermaritzburg Corporation v SAB 1911 AD 515-516, 524 observed that it is impossible to consider all the circumstances that are appropriate or that would influence the mind of a purchaser.

IRC v Clay and IRC v Buchanan [1914] 3 KB 466 CA. 
circumstances he used the Aedilitian remedies. The legal question before this court was as follows: did both parties consider the future value of the business? The plaintiff was unsuccessful in proving future value, which is, in fact, very difficult to understand. ${ }^{59}$ With respect, clause 1 of the contract in the Steyn $v$ Davies stipulates:

The lessor shall sell to the lessee who purchases herewith the business known as "THE ECONOMIC DAIRY" aforesaid, all goodwill appertaining thereto ........ for the price of $£ 1100$ (ELEVEN HUNDRED POUNDS) sterling, payable to the lessor at PRETORIA on the $1^{\text {st }}$ December, $1925 .{ }^{60}$

Instead, with respect, goodwill would force us to take note of the future prospects of this business. This would allow us to conclude that the four cows (undisclosed calving) would only temporarily be unable to produce milk, but in the future four additional cows will contribute positively to the future production of milk (future value).

In Phame $v$ Paizes the court did not consider the concept 'economic life' and as a result the dictum et promissum comprised the corner stone of that judgment. Instead, with respect, rent was the main source of income in Phame $v$ Paizes and rent increases over time as a result of various economic circumstances, for example, new tenants and the time value of money, only to add future value to this particular business. ${ }^{61}$

\section{Compromise and other methods to reduce future uncertainty}

\subsection{Equity and "equity", two of the same?}

59 At 659. Owing to the English common law principles.

60 At 657. My emphasis.

61 Correia et al. Financial Management 723. 
During the Justinian period a compromise or receptum arbitrii was recognised as an enforceable contract (pactum) ${ }^{62}$ Now we consider the following problem: how does one identify a compromise as pactum? There are two views. ${ }^{63}$ Firstly, a pactum exists only if it does not alter the essentialia of a contract. A clear example would be a contract of sale. The essentialia of such a contract of sale are merx and price. Thus, if the parties to the contract alter the price of the thing, a new contract will exist between the parties because dissensus would have destroyed the previous contract. This approach has the following devastating consequence for any aggrieved person, which is that the new contract is not a suitable defence when the buyer is seeking Aedilitian relief, that is, to exclude the actio quanti minoris. Secondly, the court in Steyn $v$ Davies interpreted various offers and counter offers made by the seller and the buyer until the parties reached consensus on the final price as a compromise. In my view, a compromise is a sense of equity, Steyn $v$ Davies constitutes authority for pactum as a suitable defence against Aedilitian relief. ${ }^{64}$

We will now turn to a very interesting contractual term. If the parties are unable to reach consensus on an appropriate method to calculate the future value of an incorporeal thing, the parties could use contractual engineering to hedge future uncertainties. An excellent example would be a guarantee that the incorporeal thing is able to produce future value or added equity within a specific economic period - financial analysts consider this engineering method as an absolute forward contract. ${ }^{65} \mathrm{~A}$ positive aspect of such a guarantee is that the seller will perhaps disclose the secret of his business acumen in order for the purchaser to attain at least the same economic results in the future.

62 See Van Warmelo Inleiding 301, 317.

63 See Christie Law of Contract 505-512, i.e., the grounds to terminate a contract.

64 See Daube (ed) Studies in the Roman Law 50.

65 Correia et al. Financial Management 723-724. Guarantee is an absolute forward contract. 


\section{Conclusion}

To depart from the Phame $v$ Paizes will be difficult, but the present writer believes that the new perspectives discussed in this article would involve relatively few problems. For instance, the criticism on Darwin's evolution theory why man is not a descendant from the ape is also appropriate to in/corporeal things. Incorporeal things cannot evolve into corporeal things because the calculation and concept of value are different. The complex economic formula is not based on an exact science, the acquisition of an incorporeal thing is in fact the acquisition of hope and the future success of an acquisition depends on business acumen. Business acumen is the ability to deal with future uncertainties successfully and the uncertainties do not lay a foundation for the laesio enormis relief owing to the exceptions of this rule. Thus, due to the similarities between ancient Roman law principles it can be stated that a forward contract does lay a foundation to avoid the Aedilitian relief when acquiring incorporeal things, because incorporeal things constantly fluctuate in value. 


\section{Bibliography}

Anthony Rethinking the Rules

Anthony RN Rethinking the Rules of Financial Accounting (McGraw-Hill New York 2004)

Berelowitz 1979 De Rebus

Berelowitz J "Legal Aspects of the Valuation of Shares" 1979 De Rebus 199

Beuthin and Luiz Company Law

Beuthin RC and Luiz SM Beuthin's Basic Company Law $3^{\text {rd }}$ ed (Butterworth Durban 2000)

Black et al. Shareholder Value

Black A et al. In Search of Shareholder Value $2^{\text {nd }}$ ed (Prentice Hall London 2001)

Bloomfield Company Accounts

Bloomfield S Reading Between the Lines of Company Accounts (Right Way Plus Tadworth 2001)

Christie Law of Contract

Christie RH The Law of Contract in South Africa $3^{\text {rd }}$ ed (Butterworth Durban 1996)

Cilliers et al. Corporate Law

Cilliers HS et al. Corporate Law $3^{\text {rd }}$ ed (Butterworth Durban 2000)

Correia et al. Financial Management

Correia C et al. Financial Management $3^{\text {rd }}$ ed (Juta Cape Town 1993) 512

Daube (ed) Studies in the Roman Law

Daube D (ed) Studies in the Roman Law of Sale in Memory of Francis de Zulueta (Oxford 1959) 
De Villiers 1997 JSAL

De Villiers DS "Dra die Keiser Klere? Diskresie en Wetteloosheid in Strafregpleging - quo vadis Suid-Afrika" 1997 Journal of South African Law 615

Delport Verkryging van Kapitaal

Delport P Die Verkryging van Kapitaal in die Suid Afrikaanse Maatskappyereg met Spesifieke Verwysing na die Aanbod van Aandele aan die Publiek (LLD thesis University of Pretoria 1986)

Dempsey and Pieters Finansiële Rekeningkunde

Dempsey A and Pieters HN Inleiding tot Finansiele Rekeningkunde (Lexicon Publishers Isando 1993)

Grossfeld 1997 JSAL

Grossfeld M "The Invisible Hand: Patterns of Order in Comparative Law" 1997 Journal of South African Law 648

Hurter 1988 MBL

Hurter E "Die Regsposisie van die Koper van Ongenoteerde Aandele in die Geval van Verborge Gebreke en Wanvoorstelling" 1988 (10) Modern Business Law 134-145

Jamneck 1997 JSAL

Jamneck J "Die Konsepwetsontwerp op die Beheer van Kontraksbedinge, 1994" 1997 Journal of South African Law 637

Kerr Law of Contract

Kerr AJ The Principles of the Law of Contract $2^{\text {nd }}$ ed (Butterworth Durban 1996) 
Kilian 2005 Comp Lawyer

Kilian CG "Legal Nature of the Company's Constitution and the Incidence of Ordinary damages" 2005 (26) The Company lawyer 154

McGregor's Security Exchange Digest

McGregor's Security Exchange Digest: The Complete South African Investor's Guide to Shares \& Unit Trusts $7^{\text {th }}$ ed (Pretoria PSG Online 20022003)

Moster, Joubert and Viljoen Die Koopkontrak Mostert DF, Joubert DJ and Viljoen G Die Koopkontrak (Butterworth Durban 1972)

Naudé Maatskappy Direkteur

Naudé SJ Die Regsposisie van die Maatskappy Direkteur met Besondere Verwysing na die Interne Maatskappyverband (Butterworth Durban 1970)

Nortjé Dividende

Nortjé C Die Inligtingswaarde van Dividende (MCom thesis Unisa 1997)

Pretorius et al. Company Law

Pretorius JT et al. Hahlo's South African Company Law Through the Cases $5^{\text {th }}$ ed (Juta Cape Town 1991)

Public commentary Sake Rapport 3

Public commentary "Makelaars Moet 'n Nuwe Pad Volg" Sake Rapport 2 June 20023

Schulze 2001 SA Merc LJ

Schulze WG "The Sources of the South African Banking Law - A TwentyFirst Century Perspective (Part II)" 2001 SA Merc LJ 616

Steiner Financial Calculations

Steiner R Mastering Financial Calculations (Prentice Hall London 1998) $28 / 31$ 
Van Warmelo Inleiding

Van Warmelo P 'n Inleiding tot die Studie van die Romeinse Reg (Balkema Cape Town 1965)

Vigario Accounting

Vigario FAA Managerial Accounting and Finance $2^{\text {nd }}$ ed (F Vigario Kloof 1997)

Vintcent Be Your Own Broker

Vintcent C Be Your Own Broker $3^{\text {rd }}$ ed (Prentice Hall London1999)

Walsh Ratios

Walsh C Key Management Ratios (Prentice Hall London 1996)

Wessels 1920 SALJ

Wessels JW "The Future of Roman-Dutch Law in South Africa" 1920 South African Law Journal 265

Wessels Law of Contract

Wessels JW Law of Contract in South Africa $2^{\text {nd }}$ ed (Butterworth Durban 1951)

\section{Register of court cases}

Ammonia Soda Co Ltd v Chamberlain (1918) 1 Ch 266 CA

Benson v SA Mutual Life Assurance Society Ltd 19861 SA 776 (A)

Botha v Van Niekerk 19833 SA 513 (W)

Bradford-on-Avon Assessment Committee v White 1898 (2) QB 630

Cotas v Williams 19472 SA 1154 (T) 1161

De JAger v Grunder 19641 SA 446 (A) 457

De Vries $v$ Wholesale Cars 19862 SA 22 (O)

Dean v Prince [1954] Ch 409 and [1954] 1 ALL ER 749 (CA) 
Dibley v Furter 19514 SA 76 (K)

Donaldson Investments v Anglo-Transvaal Collieries 19793 SA 731

Ex parte Natal Coal Exploration 19854 SA 279 (W) 282

Ex parte Satbel (Edms) Bpk: In re Meyer v Satbel (Edms) Bpk 19844 SA 347 (W) 359

Gradwell (Pty) Ltd v Rostra Printers Ltd 19594 SA 419 (A) 423

Holmdene Brickworks (Pty) Ltd v Roberts Construction Co Ltd 19773 SA 670 (A)

Janse van Rensburg v Grieve Trust CC [1999] 3 All SA 597 (C)

Katzenellenbogen v Mullin 19774 SA 855 (AD) 878

Katzoff v Glaser 19484 SA 630 (T) 636

Kingsley $v$ African Land Corp Ltd 1914 TPD 666

Knight v Trollip 19483 SA 1009 (D) 1013

Levin v Feld and Tweeds Ltd 19512 SA 410 (A) 414

Novick v Comair Holdings Ltd 19792116 (W)

Otto $v$ Heymans 19714 SA 148 (T)

Phame (Pty) Ltd v Paizes 19733397 (A)

Pietermaritzburg Corporation v South African Breweries Ltd 1911 AD 515

$S v$ Isaacs 19682 SA 187 (D)

Salisbury Portland Cement Co Ltd v Edwards Timber \& Lime Industries

(Private) Ltd 19622 SA 167 (SR)

Steyn v Davies 1927 TPD 651

Truman v Leonard 19944 SA 371 (SOK)

Van der Merwe $v$ Meades 19912 SA 1 (A)

Wastie v Security Motors (Pty) Ltd 19722 SA 129 (C)

Zuurbekom Ltd v Union Corporation Ltd 19471 SA 514 (A) 546

\section{Register of Internet resources}

Bergsten and Miller 1979 AJCL http://www.cisg.law.pace.edu/ 25 Mar

Bergsten EE and Miller AJ "The Remedy of Reduction of Price" 1979 (27) American Journal of Comparative Law 255-277 [Found on internet] 
http://www.cisg.law.pace.edu/cisg/biblio/bergsten.html [Date of use 25 Mar 2005]

De Condorcet 1793-1794 http://socserv2.socsci.mcmaster.ca/ 14 Feb De Condorcet JAN de Caritat Marquis 1793-1794 Esquisse d'un Tableau Historique des Progres de L'esprit Humain [Found on internet] http://socserv2.socsci.mcmaster.ca/ econ/ugcm/3/l3/condorcet/cindex1.ht $\underline{\mathrm{m}}$ [Date of use 14 Feb 2005] 